\title{
Sister Chromatid Exchange Process
}

National Cancer Institute

\section{Source}

National Cancer Institute. Sister Chromatid Exchange Process. NCI Thesaurus. Code C17136.

Any homology-dependent DNA strand exchange that occurs between sister chromatids in mitotic cells. This process is involved in creating combinations of genes that may be unique from the parent duplexes. Disruptions in this process may result in inviability, premature aging and predisposition to a broad variety of cancers. 